\title{
Improving Written Communication Skills and Mathematical Disposition of Tenth Grade IPS 4 Students by Using Think-Talk- Write (TTW) Learning Strategy at SMAN 50 Jakarta
}

\author{
Radiusman ${ }^{1}$, A. Noornia ${ }^{2}$, L. Ambarwati ${ }^{3}$ \\ 1,2,3Pendidikan Matematika, Universitas Negeri Jakarta, Jakarta \\ Email: radius_saragih@yahoo.com, antonnoornia@yahoo.com, lukita@unj.ac.id
}

\begin{abstract}
The aim of this research was to improve mathematical written communication and mathematical disposition of students by using think-talk-write (TTW) learning strategy in tenth grade IPS 4 students at SMAN 50 Jakarta 2017/2018 academic year. The design of this study was a classroom action research. The subject of this research consists of 6 students, 2 students with low written communication skills with moderate disposition skills, 2 students having medium-skilled and medium disposition ability and 2 students who have high disposition ability with medium and high disposition ability. The data collection techniques were consist of 1) Giving mathematics written communication ability test, 2) Spreading mathematic disposition questionnaire, 3) Doing filed notes, 4) Interviewing with the research subjects. The result was based on the end of the third cycle, it was obtained that all subject experienced has increase in mathematical written communication ability and 4 out of 6 subjects experienced has increase in mathematical disposition ability. Based on the results, it can be concluded that the TTW learning strategy can increase mathematical written communication and mathematical disposition ability in tenth grade IPS 4 students at SMAN 50 Jakarta 2017/2018 academic year. In this research, an improvement made at the thinking stage was to write answers on the worksheet so that students will be more passionate about thinking of how to solve problems. On the talking stage, students were not only explaining completion but also helping team members who having difficulties. On the write stage, students could write the answer using their own phrase so that they will understand more about the completion based on observations. From the results of questionnaires to increase the ability of mathematical disposition, it can be seen that students experience increased self-confidence in explaining the ideas obtained, able to solve problems in various ways and have the willingness to solve mathematical problems. Besides, when the teacher asks students to re-examine the result of the work, it can be seen that students check their work while checking if there was a problem-solving problem.
\end{abstract}

Keywords: mathematics written communication ability, mathematic disposition ability, Think-Talk Write (TTW) learning strategy

\section{Introduction}

Mathematical ability consists of the ability of representation, communication, connection, reasoning, and problem-solving. One of the mathematical abilities that must be developed is the ability in mathematical communication. Baroody (Ansari, 2016: 5) states that there are at least two reasons for developing mathematical communication, namely 1) mathematics is not only a tool for thinking but also a valuable tool that can be used to communicate ideas clearly, precisely and accurately. 2) Mathematics is a vehicle for social interaction. The same thing also expressed by Choridah (2013: 197) which states that "mathematical communication skills are high-level thinking skills that need to be developed because mathematics was a language that needs to be communicated both verbally and in writing, so that information was easy to understand".

But, in reality we found that students' written communication skills are difficult to develop. According to Hamdani (2009: 164), mathematics learning that took place, so far does not indicate an opportunity for the development of communication skills. This happen because the process of learning mathematics has always been centered on teacher. The students do not understand about what they do and write.

Suyanto (2016: 59) states that most students answer the mathematical description questions correctly but they do not explain them in detail, they only write down the numbers 
and then operate, do not know the reason for operating these numbers. The same thing was expressed by Neneng (Wijaya: 2016) who stated that the majority of students did not write solutions to problems using the correct mathematical language. Therefore, written mathematical communication ability must be corrected immediately because good mathematical written communication skills can improve the learning outcomes of students. The same thing was expressed by Wijaya (2016: 779) who stated that with good communication skills then a problem will be faster can be presented correctly and this will support solving problems.

To overcome the problem of written communication, the students must be trained to write the procedures of each problem found. A similar statement was also expressed by Pugalee (Wijaya: 2016) which stated that for students to be trained in communication skills in learning, they need to be accustomed to give arguments for each answer and give responses by others so that what is being learned becomes more meaningful for them. To measure the increase in written communication skills, some researchers previously used test questions whose results were calculated using the average difference test (Sumirat: 2014), n-gain (Elida: 2012), questionnaire (Hamdani: 2009). In this study, researchers used a written communication ability test in which the value of each indicator was developed through a holistic score table presented by Cai, J, Lane, M, and Jakabcsin, M.

Another ability that needs to be developed so that students can understand mathematics well is mathematical disposition. According to Salmaniah (2015: 2), mathematical dispositions are students' persistent attitude in solving mathematical problems. Students who have high disposition skills will be more persistent and resilient in solving mathematical problems given to them. Sumirat (2014: 24) states that students' positive attitudes towards mathematics are positively correlated to mathematics learning achievement. In line with these opinions, Choridah (2013: 199) states that students need mathematical disposition skills to survive in facing problems, take responsibility in their learning and develop good work habits in mathematics. Therefore, attitude of mathematical disposition is very influential on students.

But in reality, the attitude of students' disposition towards mathematics is still low. Syaban(2009: 130) states that mathematical dispositions have not been fully achieved because learning activities tend to be centered on educators who emphasize procedural processes. Muriana (2014: 90) states that there are still many mathematical teachers who adhere to the paradigm of transfer of knowledge in terms of making decisions in class, where interactions only occur in one direction. The same thing was expressed by Sumirat (2013: 24) who stated that one of the causes of students' low mathematical attitudes was the learning strategies used by teachers were very boring. To find out the increase in mathematical disposition abilities can be measured using several ways including using the average test (Sumirat, 2014; Taufiq, 2017) and attitude scale questionnaire (Andriani, 2016; Salmaniah, 2016). In this study, researchers used an attitude scale questionnaire and then measured using a Likert scale.

To overcome the problems above, we need a learning activity that can improve written mathematical communication skills and mathematical disposition. One learning activity that can improve written communication skills and mathematical disposition is the think-talk-write (TTW) learning strategy. This TTW learning strategy is introduced by Huinker and Laughin (Sumirat: 2014) which states that Think-Talk-Write strategies are formed through the results of thought and reflection and for organizing ideas and testing those ideas before students are expected to write.

The communication skills need to be developed by the students as well as engage in reflective thinking or dialogue with themselves, to talk and share ideas, and to write. According to Porter (Sofia: 2016), the TTW learning strategy is learning where students are given the opportunity to learn from beginning by understanding problems first, then actively involved in group discussions, and finally writing with their language the results of learning objectives. According to Ansari (2009: 69), TTW learning strategy has three stages, namely the think stage where students read a mathematical text or contain mathematical story questions and then take notes on what they have read, the second stage is the talking stage 
where students talk about their investigation in the first stage using their language, and the last is the writing stage where students re-write the results of their discussion using their own languages.

According to Sumirat (2014: 26), the use of TTW learning strategies can show the results of students' reflections and ideas as outlined in written form and the TTW strategy suppressor is carried out at the talk and write stages. This is because at the talk stage is a means for students to communicate well between group members and educators. While at the writing stage it can be seen that students are able or not to understand the problems faced. Sofiany (2016: 270) states that the use of TTW learning strategies can facilitate students to practice verbally and in writing fluently. Paradita (2016: 12) states that learning activities with the TTW strategy state that students do guidance to students who have difficulty in solving problems. The improvement of the TTW strategy stages in this study is at the talking stage, where the researcher writes the answers to the problems given so that they are expected to be able to stimulate students to find ideas for solving problems. In the talking stage, students not only explain ideas to group friends but also help group friends in solving problems.

In the talking stage, teachers give freedom to students to write work results in their language. This is intended so that students are no longer ask group friends about the solutions obtained in the previous stage.

\section{Methods}

The method of this research is classroom action research (CAR). In this study, researchers act as observers while teacher act as implementers of activities in the classroom. The subjects of this study were 6 students taken from 36 students which consisted of 2 students having low communication skills with moderate disposition abilities, 2 students who have medium communication with moderate disposition abilities and 2 students having high communication people with medium and high disposition abilities. The subject of this research was obtained by giving a preliminary test where the questions provided contained written mathematical communication indicators and questionnaires. The data collection technique in this study was by giving a test of written communication skills, spreading questionnaires on disposition skills, conducting observations and conducting interviews.

Mathematical written communication skills of students are measured through a description of a total of 4 questions in which each question contains an indicator of mathematical written communication skills. The results of these mathematical written communication skills tests will be measured using a holistic rubrics score.

The mathematical disposition ability of students will be measured using a questionnaire. This mathematical disposition questionnaire contains 38 statements containing indicators of mathematical disposition abilities. The statements in the questionnaire consist of positive statements and negative statements. each statement consists of 5 attitude choices. The results of the questionnaire from students will be measured using a Likert scale.

The next data collection is making observations. This observation is written in the form of field notes. This field note contains the activities carried out by educators and students during the activity. This is done to see the implementation of learning activities and problems that occur in the classroom.

The next data collection is an interview. This interview is conducted by researchers after the cycle ends. This interview aims at finding out the benefits of implementing learning activities using think-talk-write learning strategies and getting suggestions from students for the next cycle of implementation.

In this study, data validation is needed. Data validation is a strength of qualitative research. Creswell (2016: 269) states "validation is an attempt to examine the accuracy of the results of research by applying certain procedures. The validation technique used in this study was triangulation and member checking. 
Triangulation is a technique of checking the validity of data that uses something outside of research as a comparison of data that has been collected by researchers and uses it to build coherent themes justification. In this study, researchers matched the research data taken from various data retrieval techniques such as the results of written communication tests, mathematical disposition results, observations, field notes and interviews with research subjects. The aim is to understand and draw conclusions about an event that occurred during the study.

The next data validity is member checking. Member checks are carried out to determine the accuracy of the research results. These member checks are carried out by bringing the final report back to the participants to check whether the report is accurate. The process of member checks was carried out by the research subjects and observers involved in data collection.

\section{Results and Discussion}

Based on the results of the mathematical written communication test and the mathematical disposition questionnaire of students at the pre-cycle stage obtained 6 research subjects with details of 2 students having low communication skills with moderate disposition abilities, 2 students who have medium communication people with medium disposition abilities and 2 students who have high communication people with moderate disposition abilities and high. Through learning activities during the first cycle using TTW learning strategies can be obtained from the results of increased written mathematical communication skills and mathematical positions of students in Figure 1 and Figure 2 below.

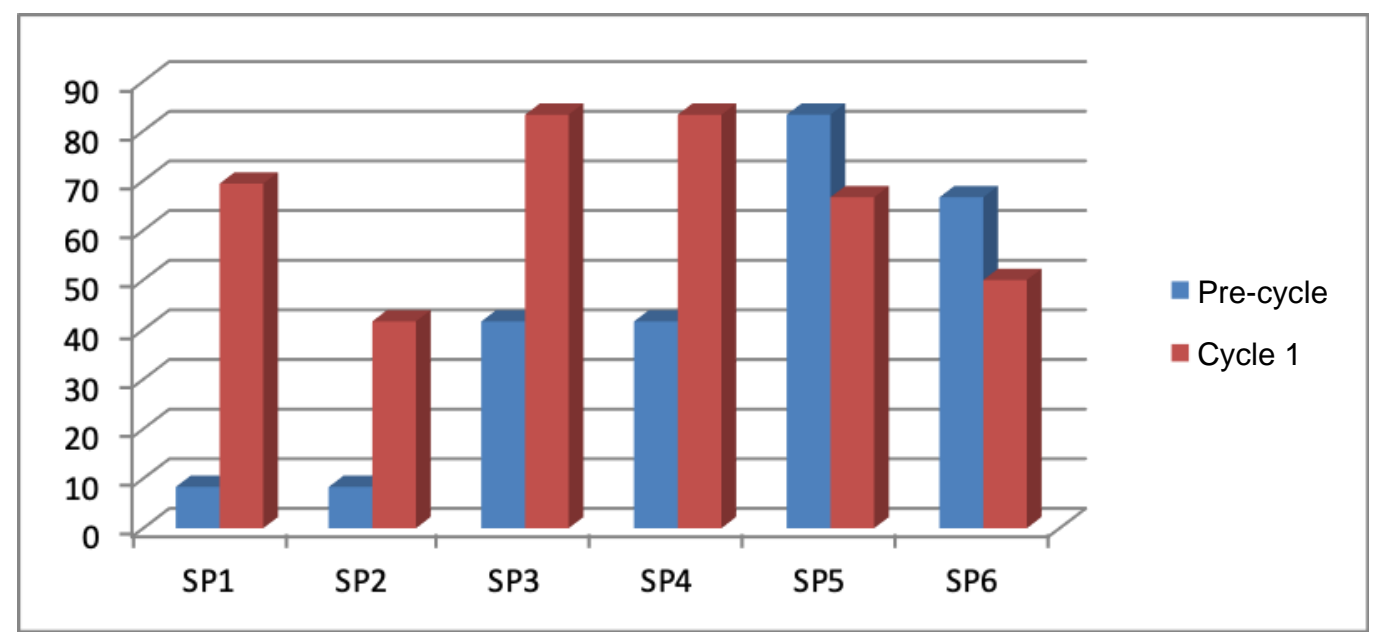

Figure 1 Mathematical Written Communication Ability Results at the End of Cycle I

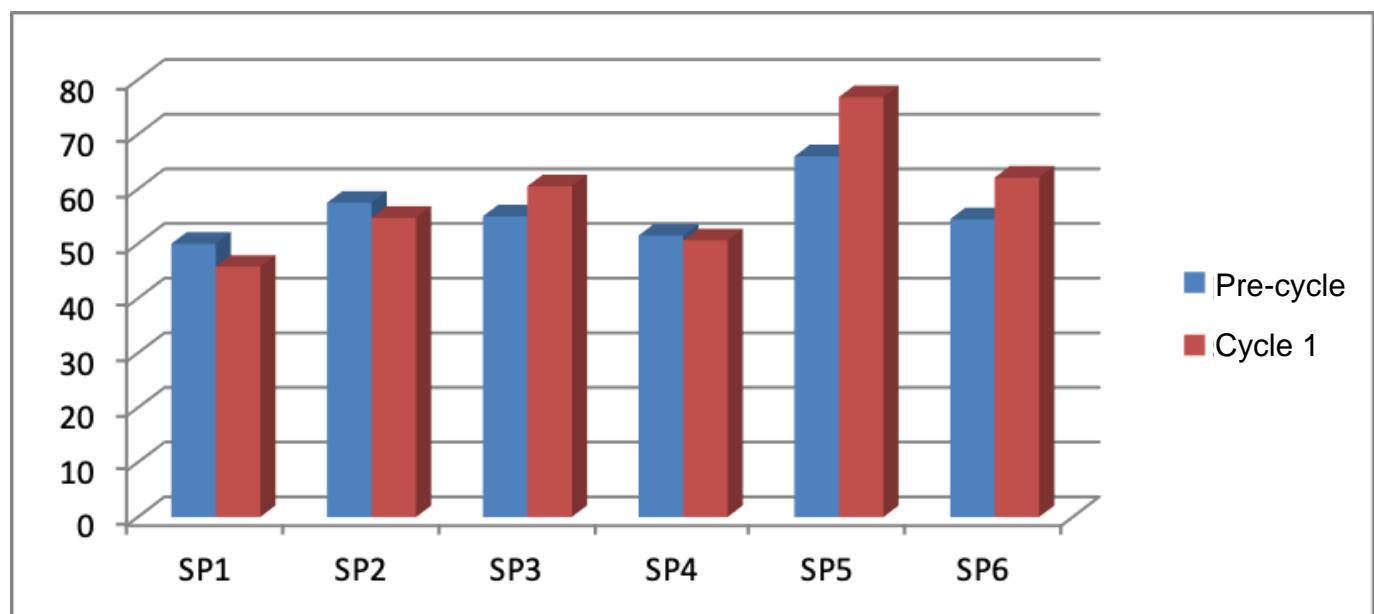

Figure 2. Results of Mathematical Disposition Ability of Students at the End of Cycle I 
Based on the implementation of the cycle I, 4 of 6 research subjects experienced increased in written mathematical communication skills and 3 of 6 research subjects experienced increased in mathematical disposition abilities. Based on the results at the end of the first cycle, it can be concluded that indicators of success have not yet been achieved. The improvements made in the second cycle are 1) Giving additional time in the talk and write stages, 2) Writing the answer key on the last sheet of LKPD which aims to stimulate students to do the thinking stage, 3) Teacher must play an active role in overseeing student activities. After teachers make improvements in the second cycle, changes in the improvement of written communication skills and students' mathematical disposition can be seen in Figure 3 and Figure 4 below.

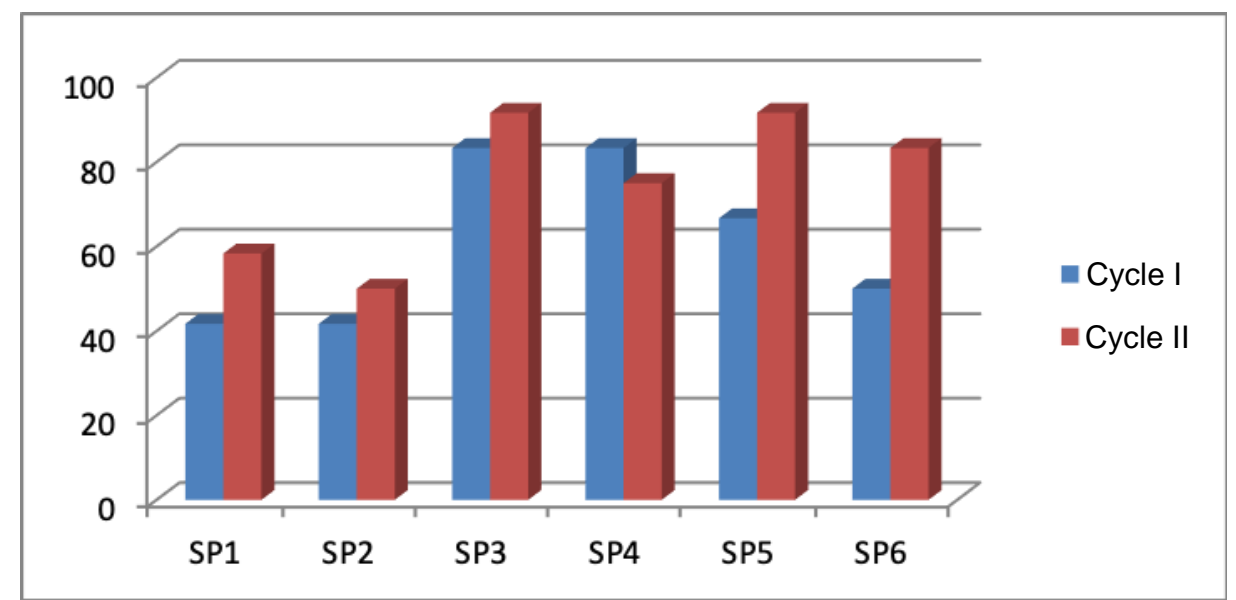

Figure 3 Mathematical Written Communication Ability Results at the End of Cycle II

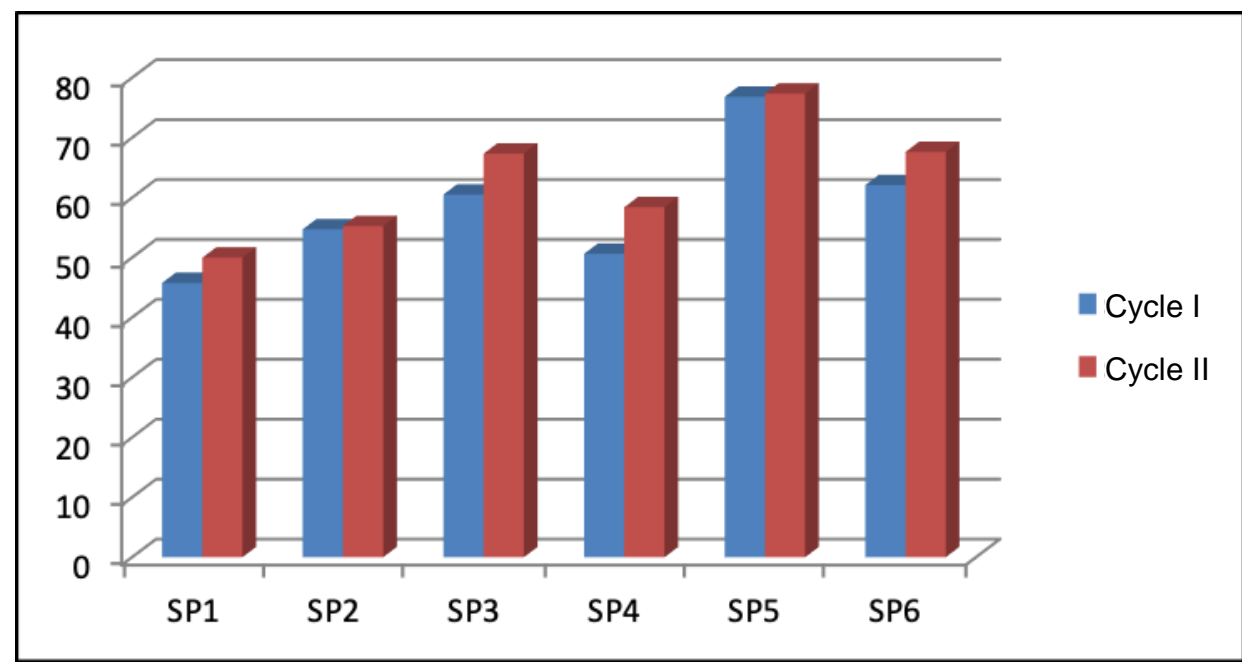

Figure 4. Results of Mathematical Disposition Ability of Students at The End of Cycle II

Through Figure 4 and Figure 5, it can be seen that at the end of the second cycle, 5 out of 6 research subjects experienced an increase in written communication skills and the six research subjects experienced increased in mathematical disposition. Nevertheless, in this study cycle III will be carried out by modifying one of the stages to see whether the increase that occurs in students was still significant or not. The improvements made by researchers are 1) When the implementation stage was done flexibly, 2) Educators call on students who still experiencing problems with mathematical communication skills and mathematical dispositions, 3) In addition to supervising students, educators do motivational activities to students who experience problems written mathematical communication skills 
and mathematical dispositions. After the improvement of the stages in the implementation of cycle III, the changes in the results of written communication skills and mathematical disposition obtained at the end of cycle III can be seen in Figure 5 and Figure 6 below.

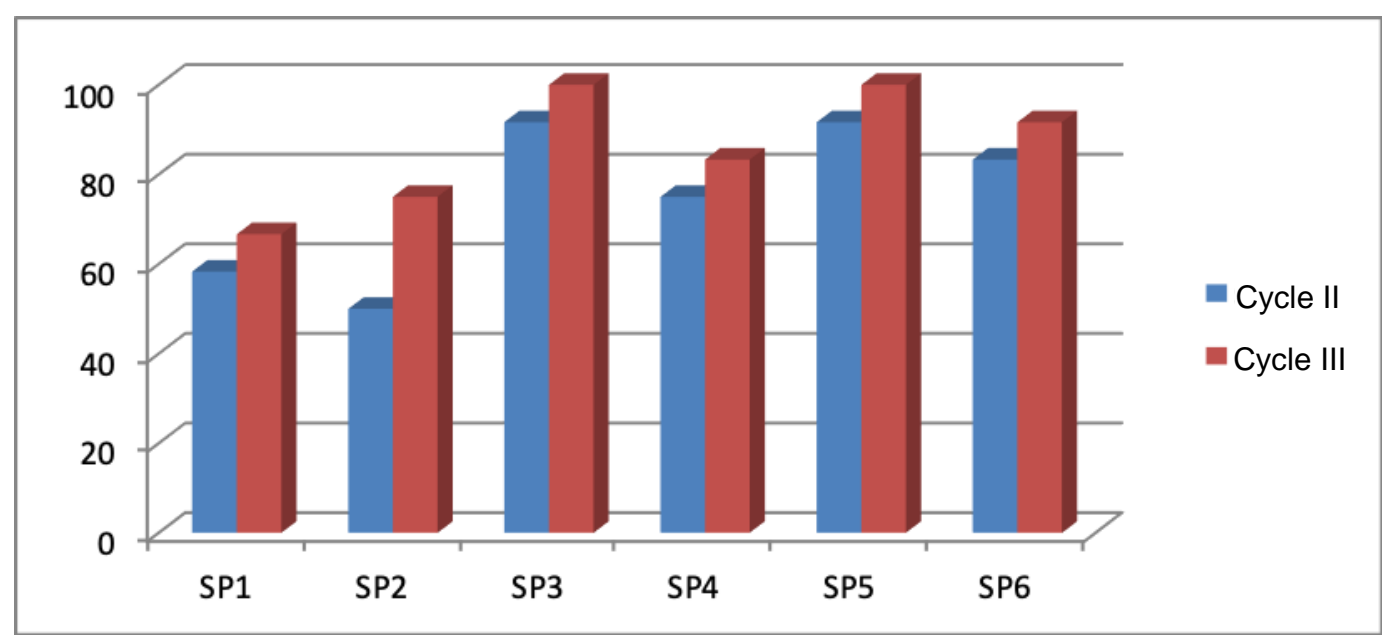

Figure 5. Results of Mathematical Written Communication Ability at the End of Cycle III

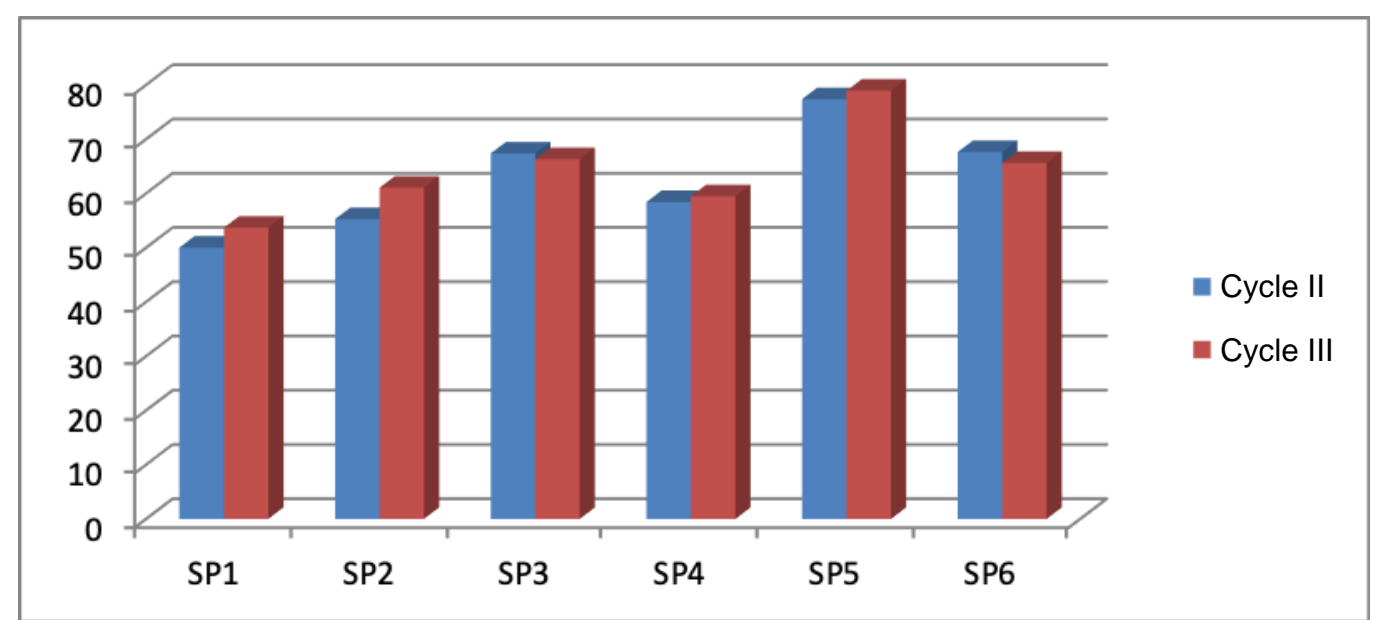

Figure 6. Results of Mathematical Disposition Ability of Students at the End of Cycle III

Through Figure 5 and Figure 6 it can be seen that the six research subjects experienced an increase in mathematical written communication skills and 4 of 6 research subjects experienced an increase in mathematical disposition.

Based on the results obtained at the end of the third cycle, the indicator of the success of the action has been reached and the changes in improvement that occur in the students were no longer significant compared to the previous cycle, therefore the continuation cycle stopped. The development of the TTW learning strategy that was carried out was at the thinking stage that educators must be able to make problems related to daily life, so that students can feel the usefulness of mathematics in their lives. Besides, teachers must also make a key answer to the problem on the worksheet. At the talk stage, the students who have high communication skills did not only explain the resolution of the problem, but also helped friends who were experiencing difficulties.

At the write stage, the teacher gave freedom by having students to write solutions in their own words. When presented their answers, the teachers calls on students who have low communication skills and a low level of disposition. It aimed to make students able to increase self-confidence. 


\section{Conclusions}

Based on the results and discussion it can be concluded that 1) TTW learning strategy can improve students' written communication skills in class X IPS 4 of SMAN 50 Jakarta. This is obtained based on the results of the final tests carried out in each cycle and improvements to the learning plan carried out in each cycle and the implementation of these improvements which are carried out during the activity. 2) TTW learning strategy can improve students' mathematical disposition abilities in class X IPS 4 of SMAN 50 Jakarta. This is obtained based on the results of the questionnaire tests conducted in each cycle, through the implementation of improvements carried out in learning activities as well as through observing the activities carried out by students during learning conducted by observers where students have more desire to learn mathematics and have confidence during math learning activities.

Based on the results of the study, the suggestions put forward include 1) for educators, it is expected to be useful as an alternative in an effort to improve quality, and learning creativity especially in mathematics at 50 Jakarta Public High Schools, 2) For students, this research is expected to be useful in an effort to improve written communication skills and mathematical disposition of students, so that competence in mathematics can be achieved optimally, 3) for related components namely school committees and education councils, the results of this study are expected to be useful as input in developing school quality improvement programs especially for mathematics subjects, 4) as input for other similar researchers that before conducting research, first explain in detail to the teacher about the appropriate stages so that the implementation of learning activities can run well and correctly, 5)This research is expected to be used as a guideline by educators to overcome the same problems with this research sample.

\section{References}

Andriani R, Isrok'atun, Kurniadi Y. 2016. Pendekatan Realistic Mathematics Education Untuk Menigkatkan Kemampuan Koneksi Matematis dan Disposisi Matematis Siswa. Jurnal Pena Ilmiah. Vol.1. No.1: 991-1000.

Ansari, B. I. 2015. Komunikasi Matematik Strategi Berfikir dan Manajemen Belajar. Banda Aceh: Penerbit Pena.

Cai J, Lane S, Jacebsin MS. 1998. Assessing Students Mathematical Communication. School Science and Mathematics Journal. Vol. 96 . No. 5: 238-246.

Choridah DT. 2013. Peran Pembelajaran Berbasis Masalah untuk Meningkatkan Kemampuan Komunikasi dan Berpikir Kreatif serta Disposisi Matematis Siswa SMA. Jurnal IImiah Program Studi Matematika STKIP Siliwangi Bandung. Vol.2. No.2: 194202.

Elida N. 2012. Meningkatkan Kemampuan Komunikasi Matematika Siswa Sekolah Menengah Pertama Melalui Pembelajaran THINK-TALK-WRITE (TTW). Jurnal IImiah Program Studi Matematika STKIP Siliwangi Bandung. Vol.1. No.2: 178-185.

Hamdani. 2009. Pengembangan Pembelajaran Dengan Mathematical Discourse dalam Meningkatkan Kemampuan Komunikasi Matematik pada Siswa Sekolah Menengah Pertama. Prosiding UNY. ISBN: 978-979-16353-3-2: 163-173.

Muriana, Hasratuddin. 2014. Peningkatan Kemampuan Komunikasi dan Disposisi Matematik Siswa SMA di Kecamatan Medan Area dengan Menggunakan Model Pembelajaran Kooperatif Tipe Grup Investigation. Pendidikan Matematika Paradikma. Vol 7 No. 1: 87-101.

Paradita Y, Sukasno, Wahyuni R. 2016. Penerapan Strategi THINK-TALK- WRITE (TTW) Terhadap Kemampuan Pemahaman Konsep Matematika Siswa Kelas VIII SMP Negeri Muara Beliti Tahun Pelajaran 2016/2017. Artikel IImiah STKIP- PGRI Lubuklinggau.

Salmaniah F, Yusmin E, Nursangaji A. 2015. Disposisi Siswa Ditinjau dari Kemampuan Problem Solving. Vol.5 No.6: 1-12.

Sopiany HN., Hijjah IS. 2016. Penggunaan Strategi TTW (THINK- TALK- WRITE) dengan Pendekatan Kontekstual dalam Meningkatkan Kemampuan Pemecahan Masalah dan 
Disposisi Matematis Siswa MTsN Rawamerta Karawang. JPPM. Vol.9. No. 2: 268276.

Sumirat LA. 2014. Efektifitas Strategi Pembelajaran Kooperatif Tipe Think- Talk- Write (TTW) Terhadap Kemampuan Komunikasi dan Disposisi Matematis Siswa. Jurnal Pendidikan dan Keguruan. Vol 1. No.2: 21-29.

Suyanto E. 2016. Pembelajaran Matematika dengan Strategi TTW Berbasis Learning Journal untuk Meningkatkan Kemampuan Menulis Matematis. Jurnal Matematika Kreatif- Inovatif. Vol.7 No. 1. 58-65.

Syaban M. 2009. Menumbuhkembangkan Daya dan Disposisi Matematis Siswa Sekolah Menengah Atas Melalui Pembelajaran Investigasi. Jurnal EDUCATIONIST. Vol.III. No.2: 129-136.

Taufiq. 2017. Pendekatan Kontekstual dan Strategi Think-Talk-Write untuk Meningkatkan Kemampuan Pemecahan Masalah dan Disposisi Matematik Siswa SMP. Jurnal Numeracy. Vol. 4. No. 1: 1-13.

Wijaya HPI., Sujadi I, Riyadi. 2016. Kemampuan Komunikasi Matematis Siswa Sesuai dengan Gender dalam Pemecahan Masalah pada Materi Balok dan Kubus (Studi Kasus pada Siswa SMP Kelas VIII SMP Islam Al- Azhar 29 Semarang). Elektronok Pembelajaran Matematika. Vol. 4 No. 41. November 2016: 778-788. 